\title{
A coal petrographic source rock evalution of the Rhaetic - Jurassic - Lower Cretaceous sediments of the Børglum 1 and Uglev 1 wells, Denmark
}

\author{
BIRTHE J. SCHMIDT
}

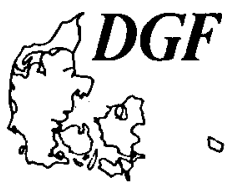

Schmidt, B. J.: A coal petrographic source rock evaluation of the Rhaetic-Jurassic-Lower Cretaceous sediments of the Børglum 1 and Uglev 1 wells, Denmark. Bull. geol. Soc. Denmark, vol. 33, pp. 239-252, Copenhagen, February, 28th, 1985.

\begin{abstract}
The Rhaetic - Jurassic - Lower Cretaceous sediments from the Børglum 1 and Uglev 1 wells have been investigated by coal petrographical methods to evaluate their hydrocarbon source rock potential. The methods include vitrinite reflectance analyses of maturity, optical qualitative rating of the composition of the dispersed organic matter in the sediments, along with an estimation of the total organic carbon content of the sediments.

The composition of the sedimentary organic matter is highly influenced by the palaeogeographic conditions. In the Børglum 1 well the organic material is dominated by land-derived (mainly gas-prone) plant matter; this is also the case for the marine sediments due to introduction of plant material from the adjacent Fennoscandian Border Zone. The sediments in Uglev 1 also have a high content of terrestrial plant material, although there is more marine dominated (oil-prone) organic matter in the deposits of the Bream Formation.

The most promising conditions for generation of liquid hydrocarbons have been found in the Bream Formation in Uglev 1, but the investigated sediments are generally thermally immature, with a restricted potential for hydrocarbon generation.

The rank gradient for Uglev $1(0.20 \% \mathrm{Ro} / \mathrm{km})$, which is situated over a deep-seated salt diapir is more than three times that of Børglum $1(0.06 \% \mathrm{Ro} / \mathrm{km})$, which is placed more marginally in the Danish Subbasin. This is attributed to differences in the geothermal gradients (Børglum 1: 19 ${ }^{\circ} \mathrm{C} / \mathrm{km}$, Uglev 1: 32 and $37^{\circ} \mathrm{C} / \mathrm{km}$, uncorrected).
\end{abstract}

Birthe J. Schmidt, Department of Phytopalaeontology, Institute of Geology, University of Aarhus, DK8000 Aarhus C, Denmark. March 7th, 1984.

\section{Introduction}

Oil and gas is formed from the disseminated organic matter in sedimentary rocks by complex physico-chemical reactions (Philippi 1965, Dow 1977).

During burial, organic matter matures with increasing temperature and duration of heating, and provided that the organic matter in the sediment makes up an adequate amount and has a suitable composition, it will be able to generate and release oil or gas at an appropriate depth.

Since disseminated organic particles in sediments principally consist of the same components as coal, and the biochemical and geochemical reactions during maturation of the organic matter are analogous to coalification processes (Stach et al. 1975, Dow 1977), coal petrographical nomenclature can be used.
Teichmüller \& Teichmüller (1958) discussed the relationship between coal rank and generation of oil and gas, and since then coal petrographical methods have been widely used for maturation analysis of dispersed organic matter. Huminite/vitrinite reflectance is today the most widely used optical technique for determining maturity (Tissot \& Welte 1978, Stach et al. 1975, 1982, Durand 1980, Hunt 1979 a.o.). For the description of the coal components of the organic particles in the sediments see appendix I.

In Denmark, Rhaetic - Jurassic - Lower Cretaceous deposits are especially interesting concerning possible oil and gas occurrences because of their often large content of organic matter, thickness and good reservoir properties. Comparison with areas adjacent to Denmark indicates that the most likely source rocks are shales of Jurassic and Early Cretaceous age (Schott 1982). 
The principal source rock of the North Sea is of late Jurassic - Early Cretaceous age, known as the Kimmeridge Clay Formation and its lateral equivalents, the Børglum Member of the Bream Formation in the Norwegian Danish Basin (Barnard \& Cooper 1981) and the J-4 unit in the Central Graben (Michelsen et al. 1982).

Source rock analyses of Rhaetic - Jurassic Lower Cretaceous deposits from the Danish onshore area outside the basinal depocentre in North Jutland with the greatest sedimentary sequences and many saltdiapirs have been carried out by Thomsen (1980), Lindgreen \& Thomsen (1982) and Thomsen et al. (1983) using mineralogical, coal petrographical and organochemical methods. They showed that deposits from this sequence are premature -immature with respect to oil generation and dominated by unfavourable types of organic matter in the premature intervals.

The purpose of this investigation is to evaluate the hydrocarbon potential of equivalent deposits from two onshore wells, Børglum 1 and Uglev 1, which have not been previously investigated.

\section{Geology}

Concerning the regional geological and stratigraphical aspects and environments of deposition of the Mesozoic sequence in the Danish area, reference is made to the papers by Larsen (1966), Christensen (1974), Michelsen 1975; 1978), Bertelsen $(1978,1980)$ and Koch (1983).

The locations of the Børglum 1 and Uglev 1 wells in the Danish Subbasin are shown in figure 1. Well data are published by Sorgenfrei \& Buch (1964) and in the Well Data Summary Sheets vol. 2 (1981). A brief characterization of the sedimentary sequences in the wells is presented below.

\section{Børglum 1}

The well has been drilled to a depth of $1254 \mathrm{~m}$ into the Gassum Formation. This formation (here represented by at least $155 \mathrm{~m}$ ) is diachronous from Upper Triassic to late Sinemurian (Bertelsen 1978, 1980), but in this marginal north eastern part of the basin it is mainly of Lower Jurassic age. The deposits are dominated by light grey sand- and siltstones, interbedded with clays- tone, deposited in a deltaic to shallow-water littoral environment. Scattered lignite particles and coal beds occur (Bertelsen 1978, 1980). The overlying Lower Jurassic Fjerritslev Formation (296 $m$ thick) consists mainly of marine claystone and shale, representing changing energy levels on the marine shelf. The formation can be subdivided into four members (Michelsen 1978). In this section the sediments are relatively coarse grained, locally with a rather high content of silt and sand. The uppermost part in particular consists of coarse grained fluviatile deposits which interfinger with the subsequent Haldager Formation (Michelsen, pers. comm.). The Haldager Formation $(63 \mathrm{~m})$ is of Middle Jurassic to Oxfordian age. The lower part (Haldager Sand Member) consists of deltaic coarse grained deposits containing carbonized plant remains and coal interbedded with thin layers of claystone. The upper part (Flyvbjerg Member) consists of marine heterolithic shallow water sediments (Michelsen 1978)). The Bream Formation (241) is of Upper Jurassic to lowermost Lower Cretaceous age and comprises low energy marine sediments, deposited on the deeper part of the shelf (Børglum Member) overlain by high energy near shore sediments (Frederikshavn Member) (Michelsen 1978). In this section low energy conditions existed briefly followed by littoral/deltaic conditions. The deltaic/littoral nature of these deposits, formerly known as the "Skagen Delta" in the northern part of Jutland (Larsen 1966), is clearly reflected by the rather coarse grained nature of the glauconite-bearing sediments which contain lignite and thin coal beds. The overlying Vedsted Formation $(283 \mathrm{~m})$ is of Lower Cretaceous age and consists of marine claystone and siltstone (Larsen 1966). Sandy intercalations also occur in this part of the section.

\section{Uglev 1}

This well is situated more centrally in the Danish Subbasin. It has been drilled to a depth of $1240 \mathrm{~m}$ into a salt diapir whose caprock has been pierced at a depth of $943 \mathrm{~m}$. Triassic and Lower Jurassic deposits are missing due to halokinetic movements (Larsen 1966). The caprock is overlain by the Haldager Formation (Michelsen 1978) (61 m) which is fractured and shows vertical clay-slickensides in response to the halokinetic move- 


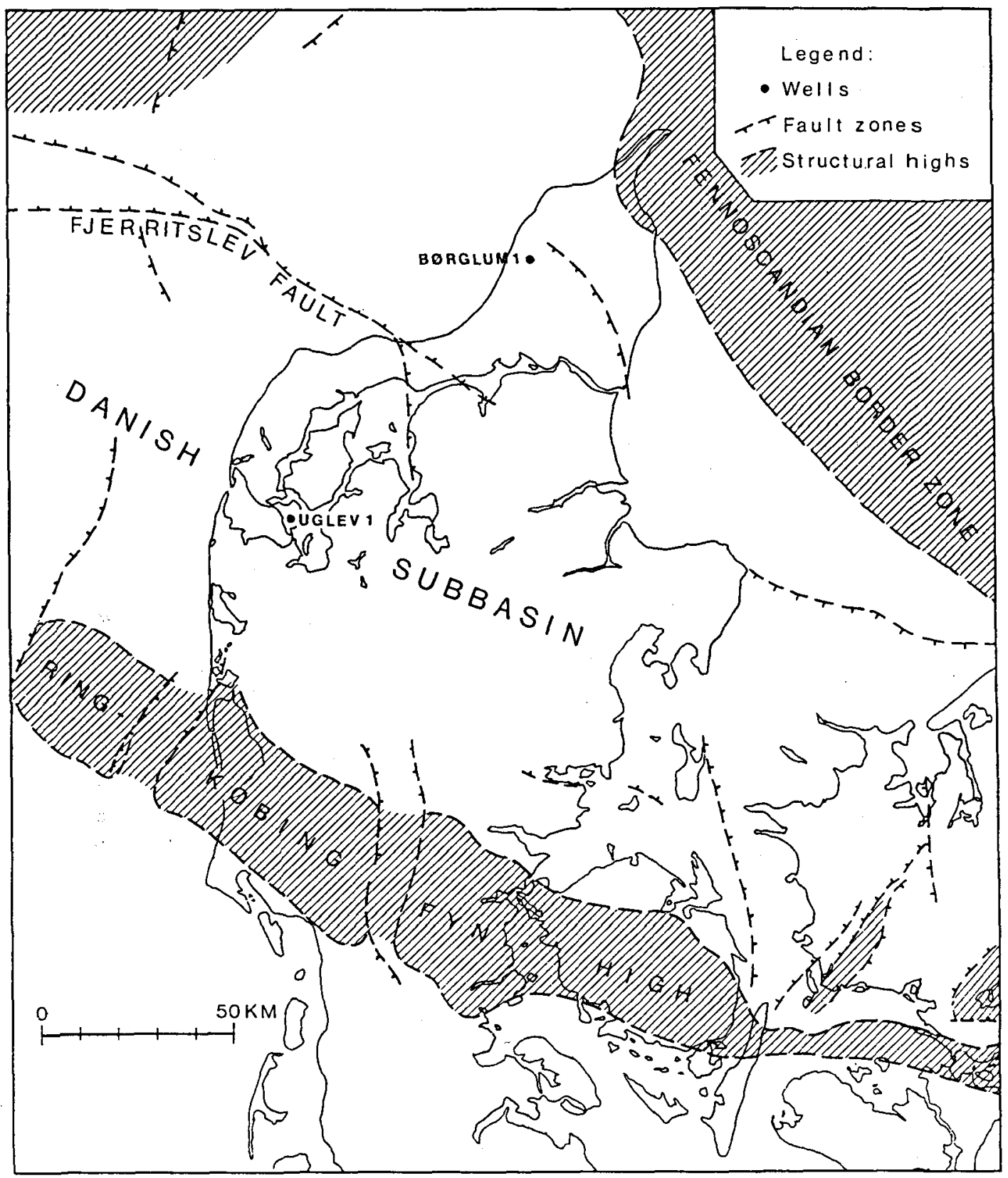

Fig. 1. Location map (modified from O. Michelsen 1978).

ments. The formation is subdivided into two members. The lower (Haldager Sand Member) comprises fluviatile/deltaic sand and siltstone interbedded with thin layers of claystone. Lignite particles, thin coal beds and local root horizons are observed in this section. The upper (Flyvbjerg Member) consists of marine heterolithic shallow water sediments. The Bream Formation $(69 \mathrm{~m})$ is thinner than the general regional thickness of $125 \mathrm{~m}$ (Michelsen 1978). Whether this is due to synsedimentary salt movement or to later erosion can not be established (Larsen 1966). The formation has not been subdivided because it does not show the typical development de- 
scribed by Michelsen (1978). The sediments consist of dark marine claystone and shale. The overlying Vedsted Formation ( $278 \mathrm{~m}$ ) consists of uniform dark marine claystone with a low content of silt. The formation is more fine grained here than in Børglum 1.

\section{Materials and methods}

The investigation is based on the core material available from the Rhaetic - Jurassic - Lower Cretaceous sequence in the wells Børglum 1 and Uglev 1, where the intervals between the cores determined the frequency of sampling.

For carbon analysis 26 samples were taken from Børglum 1 and 16 samples from Uglev 1 (table 1). For the optical analysis only one sample per core was selected from horizons with the highest organic matter content.

The amount of organic matter is expressed as the total organic carbon content in the samples. The total carbon content was calculated from the $\mathrm{CO}_{2}$ formed by combustion of finely ground samples in a Leco-induction furnace. The total organic carbon is determined in a similar way after pretreating the pulverised samples with hot, concentrated hydrochloric acid to remove any carbonates present (Tissot \& Welte 1978).

For the optical investigations, core samples are crushed to a $2-5 \mathrm{~mm}$ size to obtain representative whole rock samples. The crushed rock chips are imbedded in Araldite which hardens without heating, ground and finally polished with Tonerde 1 and 3 (Jean Wirtz, Düsseldorf).

The type of organic matter was rated qualitatively using normal reflected light supplemented with observations of the blue light induced fluorescence. Maturity og the organic matter was evaluated by huminite/vitrinite reflectance measurements. A description on methods and instruments is presented in the appendix II.

\section{Results and Discussion}

\section{Amount of organic matter}

Total carbon and total organic carbon data are presented in table 1 . It is generally considered that an organic carbon content of $0.5 \%$ repre- sents a lower limit for a source rock to generate a significant amount of hydrocarbons (Ronov 1958, Tissot \& Welte 1978). Most samples in this study, with a few exceptions mainly from the Vedsted and Gassum Formations, seem to comply with that requirement. However, the stated amounts can not be considered as mean values for the core intervals of formations in question; they represent point measurements with large interspaces, and several samples were selected on a basis of assumed maximum organic content.

The quality of organic matter in the sediments depends on the interaction between a number of factors like organic productivity, accumulation rate and degree of preservation of the organic matter (Dow 1977b, Demaison \& Moore 1980), which have been highly variable in the sediments investigated here.

The sediment samples from the Gassum Formation show a very variable content of organic carbon (from 0.11 to $3.65 \%$ organic carbon) that reflect rapidly changing sedimentary conditions in the fluviatile/deltaic environment (Bertelsen 1978, 1980). The sediments consist mainly of clean sandstone with very low contents of carbon, but thin beds of carbonaceous sandstone occur (Bø 26) with carbonized plant detritus and lignite particles. The thin, dark shale sequences (Bø 29) have a somewhat higher content of organic carbon. Large variations in the carbon contens of deltaic sediments, with up to four times more organic carbon in the clay-rich parts than in sandy channels have been noted by Huc (1980).

A large variation in the carbon values is also found in the samples from the Haldager Formation in both wells: $\mathrm{B} \emptyset 8: 0.55 \%$ to $\mathrm{B} \emptyset 10: 10.27 \%$ and Ug $36: 0.74 \%$ to Ug $39: 6.78 \%$, which likewise were deposited in a deltaic, locally non-marine environment (Michelsen 1978, Koch 1983). Thin coal beds and lignitic horizons again indicate high production, or supply of organic materials from other areas, and often excellent conservation under lowenergy, anoxic conditions. However, the sediments are very inhomogeneous and the organic matter is irregularly distributed.

Carbon values from claystone and shale samples from the marine Fjerritslev, Bream and Vedsted Formations show less fluction and values for organic carbon mainly lie between 0.5 and $1.5 \%$. As the sediments are more homogenous, these analyses are considered representative for 
Table 1.

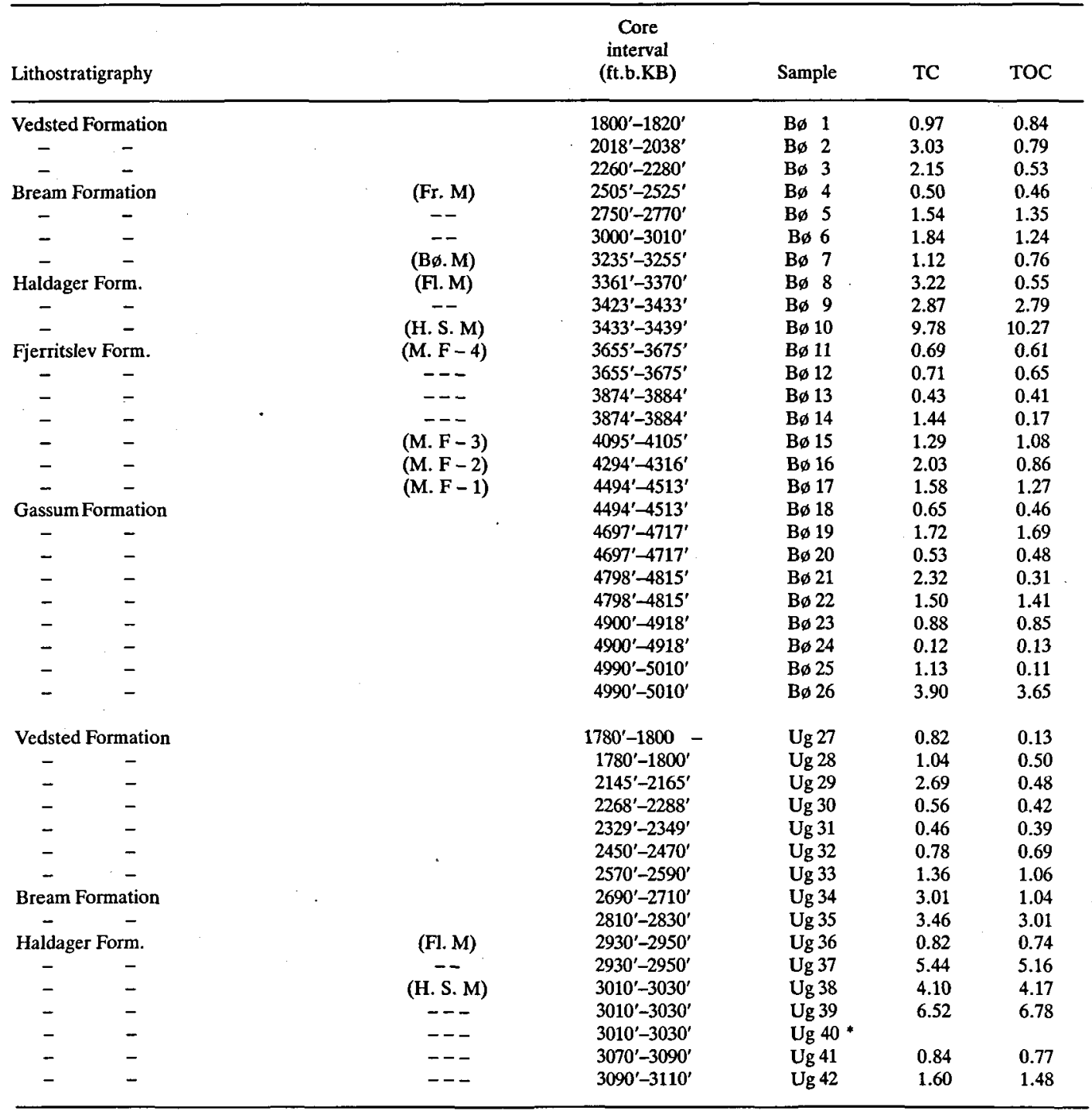

TC: Total carbon (weight percent).

TOC: Total organic carbon (weight percent).

*: not determined.

larger intervals. The highest value, $3.5 \%$ organic carbon, is from $\mathrm{Ug} 35$ in the Bream Formation, whereas the sediments of the Vedsted Formation in Uglev 1 have comparatively low contents of organic carbon, with values below $0.5 \%$ organic

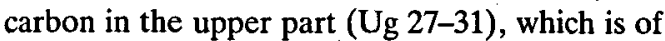
the same sediment type as the underlying Bream Formation. The content of organic carbon thus apparently decreases upwards from the Bream through the Vedsted Formation in Uglev 1, which possibly indicated changes in the interaction between depositional rate of mineral particles and production of organic matter.

The tendency for organic carbon content in fine grained sediments is well known for both old rocks (Hunt 1972, Ronov 1958, Bitterli 1963) and recent sediments (Thomas et al. 1972). The selective choice of samples makes it difficult to draw significant conclusions about this relationship here. 
Compared with values of total organic carbon in the Late Jurassic - Early Cretaceous source rocks from the North Sea area, the carbon values recorded in equivalent deposits in this study are low. Weighted average values of organic carbon for a section of black shales from the Kimmeridge Clay Formation are usually between 5\% and $10 \%$, with extremes of $1 \%$ and $30 \%$ (Barnard \& Cooper 1981), but the values vary rapidly both vertically and laterally, tending to higher values in graben depocentres. Depositional and/or preservational conditions in the investigated wells Børglum 1 and Uglev 1 were apparently less favourable.

\section{Type of organic matter}

Estimations of the composition of the organic matter are only based on the rating of the relative amounts of huminite/vitrinite, inertinite and liptinite/exinite, the latter identified using blue light induced fluorescence (Stach et al. 1975, 1982). Therefore, and because of the limited number of samples investigated, only tentative conclusions concerning the hydrocarbon potential are permitted.

Land-derived organic matter is generally found in near-shore areas and deltas, while phytoplankton represents the main source of organic matter in marine sediments, as noted by many authors (Dow 1977b, Tissot \& Welte 1978, Bostick 1979, Brooks 1980, Huc 1980 a.o.). This is also valid for the composition of the organic matter encountered in the Danish Subbasin (Lindgreen \& Thomsen 1982).

The organic matter in the deltaic/fluviatile sediments from the Gassum Formation (in Børglum 1) is dominated by terrestrial huminite/vitrinite. This is clearly seen in the sandstone samples (Bø $26, B \emptyset 22)$ which contain only very few terrestrial liptinite particles as cutinite and sporinite, and almost no inertinite. In the shaly samples (Bø 19, $\mathrm{B} \emptyset 23)$ the composition is more variable but difficult to estimate because of the small size of the particles. The humic composition of the organic matter has only a low potential for liquid hydrocarbons but a definite potential for gas.

The organic matter in the sediments from the Fjerritslev Formation also contains a large terrestrial component. Huminite/vitrinite macerals dominate, but many of the particles are re- worked, especially in $\mathrm{B} \emptyset 13$, but also to some extent in $B \emptyset 15$ and $B \emptyset 16$. The same tendency has been observed by Lindgreen \& Thomsen (1982). This can possibly be attributed to the near shore depositional environment, with oxidation of the land derived plant material occurring during transport or bioturbation (Hood \& Castano 1974). Bituminite is the dominant liptinite maceral (particularly in Bø 12) though it has a lower absolute abundance. The hydrocarbon potential is therefore difficult to estimate. The hydrocarbon potential can be reduced because of the large content of reworked huminite/vitrinite, while the locally observed content of bituminite implies a good oil potential.

Samples from the deltaic/littoral sediments from the Haldager Formation are characterized by non-marine conditions, as seen in $U g$ where exclusively autochtonous huminite/vitrinite (rootlets) are observed. As in the Gassum Formation all the samples are dominated by large huminite/vitrinite particles, but often with a higher content of terrestrial liptinites, especially of cutinite fragments and sporinite (in $B \emptyset 10, B \emptyset$ $8, \mathrm{Ug} \mathrm{36}$ ), while other liptinite macerals are rare. In $B \emptyset 10$ cutinite is even seen associated with fluorinite. Inertinite and reworked huminite/vitrinite are observed in large amounts in B $\emptyset 10$, otherwise the inertinite content is minor. The hydrocarbon potential must mainly be gas, though the relatively large content of liptinite can locally contribute with waxy oil components in the higher molecular weight range (Tissot \& Welte 1978).

In the Bream Formation deposits the composition of the organic matter is different in the two wells. In Børglum 1 marine sediments from the lower part of the formation (Bø 7 - Børglum Member, Bø 6-Frederikshavn Member) contain huminite/vitrinite and liptinite in about equal amounts. The relatively high content of liptinites is dominated by small fragments of liptinite (liptodetrinite), possibly marine singlecelled algae (Teichmüller \& Ottenjann 1977). The upper part of the formation, comprising deltaic sediments (Bø 4, Bø 5 - Frederikshavn Member), is, like the sediments in the Haldager Formation, and especially the Gassum Formation, dominated by terrestrial organic matter, principally again large huminite/vitrinite particles with small amounts of liptinite (cutinite, sporinite). In Uglev 1 samples 
from the Bream Formation are unambiguously dominated by liptinite, seen as bituminite with a finely dispersed streaky appearance in the sediments (especially Ug 35). In Ug 35 even the sedimentary matrix is fluorescent, due to lipoid substances adsorbed to the clay minerals (Teichmüller \& Ottenjann 1977). According to Teichmüller (1982) the liptinite macerals bituminite, alginite, liptodetrinite and resinite are particularly good precursors for oil, and bituminite is the predominant maceral of oil source rocks. The potential for both oil and gas is consequently rated high in the sediments comprising the marine claystones in the lower part of this formation. As the huminite/vitrinite content is rather high in the Børglum 1 deposits the most promising source-rock potential with respect to oil generation is in the organic-rich sediments from $\mathrm{Ug}$ lev 1 . The dominant maceral bituminite resembles the brown, fluorescent, structureless organic matter (sometimes associated with minor macerals such as reworked vitrinite and/or liptinites) seen in bacterially derived source rocks (Gutjahr 1983). The Kimmeridgian oil source rocks of the North Sea belongs to this source rock group.

In the Vedsted Formation the composition of the organic matter is uniform (especially in Uglev 1) and characterized by a low content of organic particles, in accordance with the carbon analyses. Quantitative rating of the maceral types is therefore difficult, generally consisting of huminite/vitrinite with a somewhat varying content (especially in Børglum 1) of liptinite. Many huminite// vitrinite particles show a clear evidence of reworking with rounded edges, oxidation rims and drying cracks. Because of the low content of organic matter and extensive oxidation the hydrocarbon potential is considered to be low.

The distribution of the various maceral types described above is in good agreement with that found by Lindgreen \& Thomsen (1982) who support their results with organo-chemical analyses.

\section{Maturity}

The result of the vitrinite reflectance analysis is shown in figs. 2 and 3. The mean values og $\bar{R}_{0}$ (average of the lowest reflecting huminite/vitrinite population chosen as the indigenous autochtonous material for the series of measurements for each sample) are plotted against depth, giving a so-called maturation profile for each well (Dow 1977). Reflectance measurements were not made on samples $B \emptyset 13, B \emptyset 26$ and $U g$ 29. The organic matter in $\mathrm{B} \emptyset 13$ consists almost solely of recycled huminite/vitrinite. The content of organic material is very low in Ug 29 and particles are too small for reliable measurements. $B \emptyset 26$ exclusively contains a very low reflecting ulminite "A"-type (Stach et al. 1975) unsuitable for rank determination. Only mean random reflectance measurements have been recorded and the anisotropy, which increases with rank but first becomes pronounced above approximately $1.2 \%$ $R_{0}$, has been neglected (Stach et al. 1975, Tissot \& Welte 1978). Preliminary investigation showed that particles with reflectance values above $1.2 \%$ $\mathbf{R}_{\mathbf{o}}$ were reworked in all samples.

The chemical reactions responsible for maturation of the organic matter are governed primarily by rise of temperature and the time during which this occurs, while pressure retards the chemical reactions (Stach et al. 1975, 1982). These reactions vary linearly with time and increase exponentially with temperature (Phillippi 1965, Dow 1977). An exponential increase in maturity as expressed by vitrinite reflectance with depth is therefore predictable (assuming a constant geothermal gradient) (Dow 1977). At reflectance values below $0.6 \% R_{o}$ semilogaritmic and linear plots of the variation of these values against depth will coincide, and only linear regression analysis has been undertaken, giving the rank gradient from each well. Computation of regression is performed by the method of least squares.

The results show a high degree of correlation with increasing reflectance of $0.06 \% \mathrm{R}_{\mathrm{o}} / \mathrm{km}(\mathrm{r}=$ $0.91)$ in Børglum 1 and $0.20 \% \mathrm{R}_{\mathrm{o}} / \mathrm{km}(\mathrm{r}=0.79)$ in Uglev 1. In Børglum 1 the line intersects the surface at $0.38 \% R_{0}$, whereas in Uglev 1 it intersects the surface at $0.30 R_{0}$. The reason for the values being above $0.18-0.20 \% R_{0}$, which are the lowest measurements obtained in low rank huminite material, may be that the area ceased to be a major depositional area during Upper Cretaceous times and that part of the upper succession of strata has been removed by later glacial erosion. Another possibility for this may be differential movements in Upper Cretaceous - Tertiary or salt movements.

Since it is generally accepted that coalification 
Børglum 1

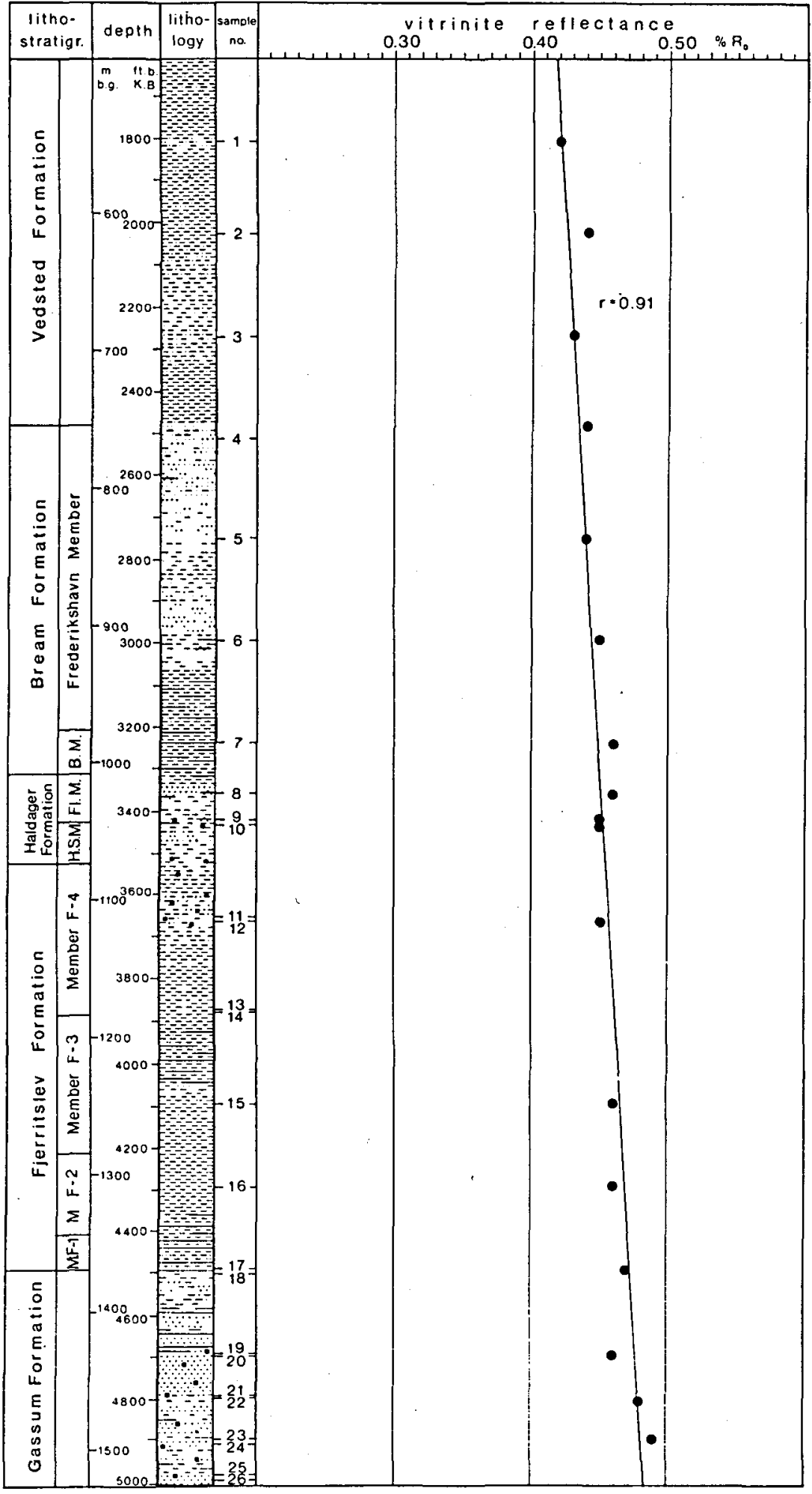




\section{Uglev 1}

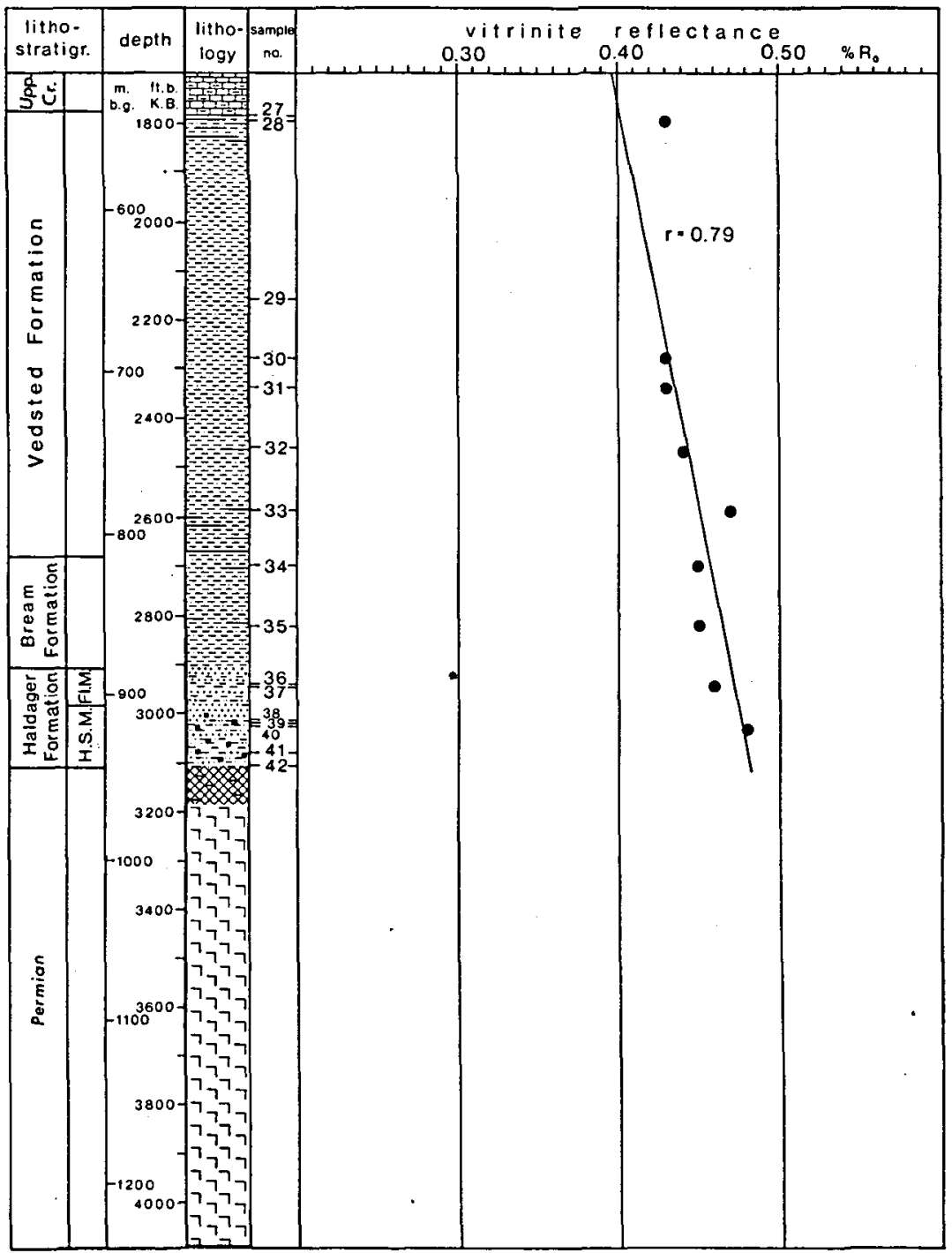

sand/sandstone

silt/tinesandstone

clay/claystone

shale

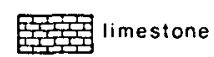

anhydrite

ㄱำ rocksalt

coal-lignite

Fig. 2 \& 3. Plot of huminite/vitrinite reflectance values against depth and calculated rank gradient. H. S. M. = Haldager Sand Member, F1. M. = Flyvbjerg Member, B. M. = Børglum Member.

(The lithology is modified from G. Larsen 1966 and O. Michelsen 1978). 
is mainly a result of the temperature to which the sediments were exposed, the geothermal gradient, or more precisely the heat flow, is, in addition to the depth of burial, decisive for the maturity attained (Teichmüller \& Teichmüller 1966, Doebl et al. 1974). Changes in geothermal conditions in an area during burial history can be traced as irregularities in reflection profiles (Robert 1980, Dow 1977).

In the Danish area the geothermal conditions and their regional variations have been described by, amongst others Madsen $(1975,1977)$, Balling (1978, 1979) and Michelsen et al. (1981) who used bottom hole temperatures from a series of deep boreholes. Their investigations show that the highest temperatures are found in those parts of North Jutland where the thickest sequences of sedimentary rocks occur and that the temperature decreases above the Ringkøbing-Fyn High and towards the Fennoscandian Border Zone. Computations yield an average value of $23.5^{\circ} \mathrm{Cl}$ $\mathrm{km}$ (uncorrected) for the geothermal gradient in Denmark (Madsen 1975, 1977).

In the regional investigation of rank conditions, Thomsen et al. (1983) determined the rank gradient in several boreholes in the Danish Subbasin and compared these with the geothermal gradients. In this way a minimum average value for regions outside the basinal depocentre has been determined to be $0.09 \% \mathrm{R}_{\mathrm{o}} / \mathrm{km}$ for the Rhaetic - Jurassic - Early Cretaceous sequence. Similar results with rank gradients of $0.06-0.09 \%$ $\mathrm{R}_{\mathrm{o}} / \mathrm{km}$ for geothermal gradients of $23-25^{\circ} \mathrm{C} / \mathrm{km}$ have been estimated for Mesozoic-Cenozoic molasse sediments in the Alpine foredeep (Stach et al. 1982).

A rank gradient of $0.06 \% \mathrm{R}_{\mathrm{o}} / \mathrm{km}$ for Børglum 1 is only in slight diseagreement with the average value determined by Thomsen et al. (1983) and is explained by the temperature gradient in Børglum 1 of only $19^{\circ} \mathrm{C} / \mathrm{km}$ (uncorrected). Furthermore, huminite/vitrinite is generally not considered to be a sensitive rank parameter for rank values below $0.50 \% \mathrm{R}_{\mathrm{o}}$ (Stach et al. 1975, 1982). The rank gradient of $0.20 \% \mathrm{R}_{\mathrm{o}} / \mathrm{km}$ determined for Uglev 1 is more than three times as great as for Børglum 1. The geothermal gradient for the well is very high, varying from $32^{\circ} \mathrm{C} / \mathrm{km}$ to $37^{\circ} \mathrm{Cl}$ $\mathrm{km}$ (uncorrected) at different depths (Madsen 1977), which is attributed to its location over a salt diapir. Anomalous temperature gradients have also been recorded in other wells lying over salt structures (Gassum $1\left(36^{\circ} \mathrm{C} / \mathrm{km}\right)$ and Thisted $1\left(33^{\circ} / \mathrm{km}\right)$ ) (Madsen 1977), because of the substantially greater heat conductivity of salt relative to sedimentary material. Model-based computations by Balling (1977) show that this, in connection with morphology of the salt structures, may result in substantial temperature and heat flow anomalies in and around salt structures. Reflectance analyses of Gassum 1 (Thomsen et al. 1983) thus show a correspondingly high rank gradient $\left(0.21 \% \mathrm{R}_{\mathrm{o}} / \mathrm{km}\right)$.

Reflectance analyses show that the investigated materials are immature in both wells, with $\mathrm{R}_{\mathrm{o}}$-values below $0.50 \% \mathrm{R}_{\mathrm{o}}$ which, according to Tissot \& Welte (1978), is the minimum value for onset of oil genesis. This is confirmed by other microscopic observations which show a low degree of coalification of the primary organic material with appearance of brown coal. The samples with the highest degree of coalification are equivalent to the subbituminous B/A coal rank, which in a coal petrographic sense indicates the transition between lignite and bituminous coals (Stach et al. 1975). The results are supported by the observation that the mineral-bituminous matrix in Ug 35 shows a strong positive alteration (increased fluorescence intensity) after $30 \mathrm{~min}$ utes irradiation with blue light, indicating immature material with reflectance values lower than $0.50 \% R_{o}$ (Teichmüller \& Ottenjann 1977). No marked change in the fluorescence colour of sporinite has been observed. Finally, no traces of hydrocarbons have been found in the wells (Sorgenfrei \& Buch 1964).

Investigations by Thomsen et al. (1983) also show that the organic material in the Rhaetic Jurassic - Early Cretaceous sequence is mainly immature to premature with respect to oil generation, with reflectance values between 0.36 and $0.58 \% \mathrm{R}_{\mathrm{o}}$. Their results are confirmed by fluorescence measurements (red/green ratio determinations) and spore colouration (TAI index).

Different types of organic matter have different compositions and different rates of transformation in response to temperature increase (Brooks 1981, Hunt 1979, Tissot \& Welte 1978). There are no distinct limits for the onset of hydrocarbon generation in terms of vitrinite reflectance values. A comprehensive literature survey by Héroux et al. (1979) indicates that the limits 
vary rather widely, especially for the oil "birth" line. Experience from the North Sea (Thomsen et al. 1983) shows that the composition of source rock hydrocarbons only becomes crudelike in a reflectance range of $0.60-0.70 \% R_{\mathrm{o}}$.

The organic matter in the sediments of the Gassum Formation in Børglum 1 is dominated by huminite/vitrinite. Vitrinite has a chemical composition comparable to type III kerogen, which reaches maturity at a reflectance level of $0.60 \%$ $\mathrm{R}_{\mathrm{o}}$ (Tissot \& Welte 1978). By extrapolation of the rank gradient, organic matter with reflectance values of $0.60 \% R_{0}$ can be expected in Børglum 1 at a depth of $3350 \mathrm{~m}$. However, at this depth Triassic sediments with an exceedingly limited hydrocarbon potential probably occur. Apart from the Rhaetic, they most likely consist of continental redbed sequences and evaporites with a low content of organic matter (Bertelsen 1980). In the marginal area, even older deposits may be present at this depth. However, the rank gradient need not be constant as changes in the geothermal gradient may have taken place during the burial history.

The geothermal relations are anomalous around the salt structures, with positive temperature anomalies above the structure. More favourable source rock sediments may be found here which have experienced local heating and maturation (cf. Uglev 1), but the geothermal gradient will not increase with depth because of negative temperature anomalies within and near the flanks of the salt structure (Madsen 1977).

\section{Conclusion}

Because of the limited number of samples investigated only tentative conclusions are permitted and are made with reservations.

The lack of hydrocarbons must primarily be attributed the type and maturity of the organic matter as the amount of organic carbon in the analyzed samples from the Rhaetian - Jurassic Early Cretaceous sequence seems to be sufficient for the sediments to be potential source rocks, with a few exceptions mainly from the Vedsted and Gassum Formation.

The composition of the organic matter in the sediments from Børglum 1 is distinctly domi- nated by terrestrial plant material with a very restricted oil potential in most of the investigated sequence. Thin intercalations of sediments containing some marine material only occur in the lower part of the Bream Formation. This also seems to apply to the deposits from Uglev 1, but with a dominance of marine material with a favourable oil potential in the lowermost part og the Bream Formation. The large contens of terrestrial organic matter in Børglum 1, also in the marine sediments, reflects its proximity to the Fennoscandian Border Zone. The difference in the composition of the organic matter between the wells is governed by paleogeographic conditions during the sedimentation (Lindgreen \& Thomsen 1982). It seems to follow the regional trend showing a decreasing potential for liquid hydrocarbons in near-shore sediments. The most promising source rock potential with respect to oil generation in the two wells is thus found in the sediments of the Børglum Member in the Bream Formation (lateral equivalent to the Kimmeridge Clay Formation). They have a relatively high content of organic matter principally originating from liptinite, which resembles the brown fluorescent, structureless organic matter known from the so-called "bacterial source rock type" comprising the Kimmeridgian oil source rock of the North Sea (Gutjahr 1983).

However, maturation studies have shown that the sequence is immature, with reflectance values below $0.5 \% \mathrm{R}_{0}$. Immaturity has ben stressed by other microscopical observations such as the brown coallike appearance of most primary huminite macerals, no marked changed in the fluorescence colour of sporinite, and strong positive alteration of the mineral-bituminous matrix.

Uglev 1 has a much higher rank gradient than Børglum 1. Since coalification is primarily dependant on heating, the rank gradient is a function of the geothermal gradient. The higher values of both rank gradient and geothermal gradient for Uglev 1 are due to heat conduction from the underlying salt diapir. The lower values estimated for Børglum 1 are in accordance with regional values outside the basinal depocentre (Thomsen et al. 1983).

Mature Mesozoic source rock material may therefore be found at different levels in the Danish Subbasin, depending on the type of organic material and the geothermal gradient, but the 


\section{depth at which mature organic material may be found is not readily predictable.}

Acknowledgements. Im a grateful to Carlsbergfondet for financial support, and to the Geological Survey of Denmark, Copenhagen, for providing the material and permission to perform the reflectance measurements. Especially I wish to thank B. E. Koch and E. Thomsen who read an earlier draft of the paper and offered helpful suggestions, J. R. Wilson who kindly improved the English text and M. Dybdahl who typed the manuscript.

\section{Dansk sammendrag}

Rhæt-Jura-nedre Kridt lagserien fra boringerne Børglum 1 og Uglev 1 er undersøgt kulpetrografisk med henblik på sedimenternes eventuelle rolle som source-rock for kulbrinter. Hertil er anvendt vitrinitreflektionsanalyse til modenhedsbestemmelsen, en optisk kvalitativ vurdering af det organiske indhold samt en kulstofanalyse af sedimentet.

Sammensatningen af det organiske materiale er stærkt påvirket af de palæogeografiske forhold på sedimentationstidspunktet. I aflejringerne fra Børglum 1 er det organiske materiale domineret af terrestrisk (fortrinsvis gasdannende) plantemateriale, selv i de marine sedimenter pả grund af tilførsel af plantemateriale fra den nærliggende Fennoskandiske Randzone. Sedimenterne fra Uglev 1 viser ligeledes et stort terrestrisk indhold, dog med tydeligt mere marint domineret (oliedannende) organisk materiale i Bream Formationens aflejringer, hvor de gunstigste betingelser for oliedannelse findes. Modenhedsunders $\emptyset$ gelserne viser imidlertid, at det undersøgte sedimentmateriale er umodent med et meget begranset kulbrintepotentiale.

Ranggradienten for Uglev $1\left(0.20 \% R_{0} / \mathrm{km}\right)$, placeret ovenpå en saltdiapir, er mere end tre gange sả stor som for Børglum 1 $\left(0.06 \% \mathrm{R}_{\mathrm{d}} \mathrm{km}\right)$, der er mere randnært beliggende i Det danske Subbassin. Forskellen henføres til forskelle i de geotermiske gradienter.

\section{Appendix I}

Coal consists of physically and genetically different organic components known as macerals. Under the microscope these can be distinguished as petrographically distinct constituents of the dispersed organic particles of the sediment. They can be classified into three main types. For detailed descriptions reference is made to the International Handbook of Coal Petrology (1963, 1971, 1975).

Liptinite/exinite: This group covers temperature-reactive, hydrogen-rich macerals, including alginite, sporinite, cutinite fluorinite and resinite, as well as bacterial lipids and bacterial decomposition products of protein and carbohydrates (bituminite). They are often non-structured and constist of indistinguishable masses. Most liptinites/exinites are considered to be the precursors of oil and gas. Lipitinite/exinite can be characterized by their low (black) reflectance and intense fluorescence at lower levels of maturity.

Huminite/vitrinite: This group covers relatively oxygen-rich macerals, whose components are derived principally from higher land plants and essentially represent the humified remains of the lignin and cellulose of cell walls. The group in- cludes telinite and collinite. The huminite/vitrinite macerals are predominantly precursors to gas, and only minor oil precursors. Huminite/ vitrinite is characterized by an intermediate (gray) reflectance; fluorescence is usually absent.

Inertinite: Covers relatively carbon-rich and very hydrogenpoor macerals derived from the same plant materials as huminite and liptinite, but they are oxidized prior to incorpotation in the sediment. The inertinite macerals are inert and essentially unaffected by heating, so their convertibility to hydrocarbons may be zero. Inertinite is characterized by a high (white) reflectance and no fluorescence

\section{Appendix II}

The type of organic matter was qualitatively rated using normal reflected light, supplemented with observations of the blue light induced fluorescence. Methods and terminology are according to Stach et al. $(1975,1982)$.

The maturity of the organic matter is evaluated from reflectance measurements of huminite/vitrinite, where reflected light from the surface of a vitrinite grain is compared with that from a glass standard with known reflectance under identical illumination conditions.

By using whole rock samples and not organic matter concentrates the relationship between organic and mineral matter could be studied and fluorescence is also unaffected by chemicals. The dispersed organic matter in the sediment usually comprises a mixture of allochtonous and autochtonous materials, as well as various types of reworked and in other ways altered products, often with a very wide range of reflectance. So those particles which had the lowest degree of alteration when incorporated in the sediment must be selected if maturation indigenous to the rock is to be measured. Organic matter that has been altered prior to incorporation into the sediment or redeposited from older rocks, yield too high reflectance values and must be excluded. Bituminous huminite/vitrinite particles yield too low reflectance values and the darkest particles have therefore not been subjected to reflectance measurements. Instead, measurements have been concentrated on grains with a preserved tissue-structure. The reflectance of the highest possible number of low reflecting huminite/vitrinite grains on the polished surface has been recorded (Stach et al. 1975, Lindgreen \& Thomsen 1982). The difficulties involved in the choise of particles for measurements have been discussed in some detail by Bostick (1979).

\section{Instruments}

All polished sections were studied in reflected light by means of a "Zeiss Photomicroscope" equipped with a $\times 40$ "Epipol" oilimmersion objective, an adjustable lamp current stabilizing transformer with a $100 \mathrm{~W}$ halogen lamp, filters for polarized light/green light $(546 \mathrm{~nm})$, and a MP03 photomultiplier with digital read-out. "Zeiss" immersion oil $\left(\mathrm{N}_{\mathrm{d}}=1.515\right)$ was used throughout the study. The photomultiplier was calibrated on the microscope by measurements on a polished glass-standard of constant known reflectance. For qualitative fluorescence-microscopic observations the microscope was equipped with a HBO $50 \mathrm{~W}$ mercury lamp, a KP 500 exciting filter (Zeiss) was used to provide the blue light excitation, a FT 510 dichroic beam splitting mirror (Zeiss) and a LP 520 barrier filter (Zeiss) was placed in the light path to the observer. 


\section{References}

Balling, N. 1978: Geofysiske metoder til lokalisering af geotermiske energiressourcer. Dansk geol. For. Årsskr. 1977, 13-27.

Balling, N. 1979: Subsurface temperatures and heat flow estimates in Denmark. In: Cermak, V. \& Rybach, L. (eds.), Terrestrial Heat Flow in Europe. Springer Verlag, Berlin, 161-171.

Barnard, P. C. \& B. S. Cooper 1981: Oils and source rock of the North Sea area. In: Illings, L. V. \& G. D. Hobson (eds.), Petroleum geology of the continental shelf of northwest Europe. Heyden \& Son Ltd. for Inst. of Petroleum, London, 169-175.

Bertelsen, F. 1978: The Upper Triassic-Lower Jurassic Vinding and Gassum Formation of the Norwegian-Danish Basin. Danm. geol. Unders., Ser. B, 3, 1-26.

Bertelsen, F. 1980: Lithostratigraphy and depositional history of the Danish Triassic. Danm. geol. Unders., Ser. B, 4, 159.

Bitterli, P. 1963: Aspects of the genesis of bituminous rock sequences. Geol. Mijnb. 42, 183-201.

Bostick, N. H. 1974: Phytoclasts as indicators of thermal metamorphism, Franciscan Assemblage and Great Valley Sequence (Upper Mesozoic), California. Geol. Soc. America Spec. Paper 153, 1-17.

Bostick, N. H. 1979: Microscopic measurements of the level of catagenesis of solid organic matter in sedimentary rocks to aid exploration for petroleum and to determine former burial temperatures. A review. Soc. Econ. Paleont. Miner., Spec. Publ.26, 17-43.

Bostick, N. H. \& Alpern, B. 1976: Principles of sampling, preparation and constituent selection for microphotometry in measurement of maturation of sedimentary organic matter. J. Microscopy 109 (1), 41-47.

Brooks, J. 1981: Organic maturation of sedimentary organic matter and petroleum exploration: A review. In: Brooks, J. (ed.), Organic maturation studies and fossil fuel exploration. The British National Oil Corporation, Glasgow, 137.

Christensen, O. B. 1974: Marine communications through the Danish Embayment during uppermost Jurassic and lowermost Cretaceous. Geoscience and Man 6, 99-115.

Demaison, G. J. \& Moore, G. T. 1980: Anoxic environments and oil source bed genesis. AAPG Bull. 64 (8), 1179-1209.

Doebl, F. et al. 1974: Diagenesis of Tertiary clayey sediments included dispersed organic matter in relationship to geothermics in the Upper Rhine Graben. In: Illies, J. H. \& Fuchs (eds.), Approaches to taphrogenesis. Schweizerbart, Stuttgart, 192-207.

Dow, W. G. 1977: Kerogen studies and geological interpretations. J. Geochem. Expl. 7, 79-99.

Dow, W. G. 1977b: Petroleum source beds on continemtal slopes and rises. AAPG Bull. 62 (9), 1584-1606.

Durand, B. 1980: Kerogen. Technip, Paris, 1-519.

Gutjahr, C. C. M. 1983: Introduction to incident-light microscopy of oil and gas source rocks. In: van der Berg, M. W. \& R. Felix (eds.), Special issue in the honour of J. D. de Jong. Geol. Mijnb. 62, 417-425.

Héroux, Y. et al. 1979: Compilation and correlation of major thermal maturation indicators. AAPG Bull. 63 (12), 21282144.

Hood, A. \& Castano, J. R. 1974: Organic metamorphism: its relationship to petroleum generation and application to studies of authigenic minerals. United Nations $E$. S. C. A. P., Coord. Comm. Offshore Prosp. Tech., Tech. Bull. 8, Arcticle VII, 85-118.
Huc, A. Y. 1980: Origin and formation of organic matter in recent sediments and its relation to kerogen. In: Durand, $B$. (ed.), Kerogen. Technip, Paris, 445-474.

Hunt, J. M. 1972: Distribution of carbon in crust of earth AAPG Bull. 56, 2273-2277.

Hunt, J. M. 1979: Petroleum Geochemistry and Geology. W. H. Freeman and Co., San Francisco, 1-617.

International Comittee for Coal Petrology 1963: International handbook of coal petrology (2nd ed.) - Centre National de la Recherche Scientifique, Paris.

International Committee for Coal Petrology 1971: International handbook of coal petrology. suppl. to 2 nd ed. Centre National de la Recherche Scientifique, Paris.

International Committee for Coal Petrology 1975: International handbook of coal petrology. 2nd Suppl. to 2nd ed. - Centre National de la Recherche Scientifique, Paris.

Koch, J. O. 1983: Sedimentology of Middle and Upper Jurassic sandstone and reservoir of Denmark. In: Kaaschieter, J. P. H. \& T. J. A. Rejers (eds., Petroleum geology of the southeastern North Sea and the adjacent onshore areas. The Hague, 1982, Geol. Mijnb. 62, 115-129.

Larsen, G. 1966: Rhaetic-Jurassic-Lower Cretaceous sediments in the Danish Embayment. Danm. geol. Unders. II rakke, 91, 1-127.

Lindgreen, H. \& Thomsen, E. 1982: Investigations on the source rock potential of the Danish onshore area. Danm. geol. Unders. 1-91.

Madsen, L. 1975: Approximate geothermal gradients in Denmark and the Danish North Sea Sector. Danm. geol. Un ders., Årbog 1974, 5-16.

Madsen, L. 1978: Geotermisk energi i Danmark-en geologisk vurdering. Dansk geol. Foren. Arsskr. 1977, 29-40.

Michelsen, O. 1975: Lower Jurassic biostratigraphy and ostracods of the Danish Embayment. Danm. geol. Unders., II rakke, 104, 1-287.

Michelsen, O. 1978: Stratigraphy and distribution of Jurassic deposits of the Norwegian-Danish Basin. Danm. geol. Unders., Ser. B, 2, 1-28.

Michelsen, O., S. Saxov, J. A. Leth, C. Andersen, N. Balling, N. Breiner, L. Holm, K. Jensen, J. I. Kristiansen, T. Laier, E. Nygaard, J. Chr. Olsen, K. D. Poulsen, S. Priisholm, T. B. Raade, T. R. Sørensen \& J. Würtz 1981: Kortlægning af potentielle geotermiske reservoirer i Danmark. Danm. geol. Unders. Ser. B, 5, 1-78.

Michelsen, O. (ed.) 1982: Geology of the Danish Central Graben. Danm. geol. Unders. Ser. B, 8, 1-133.

Philippi, G. T. 1965: On the depth, time and mechanism of petroleum generation. Geochim. Cosmochim. Acta 29, 10211069.

Robert, P. 1980: The optical evolution of kerogen and geothermal histories applied to oil and gas exploration. In: Durand, B. (ed.), Kerogen. Technip, Paris, 385-414.

Ronov, A. B. 1958: Organic carbon in sedimentary rocks (in relation to the presence of petroleum). Geochem. 5, 497509.

Schott, W. 1982: Crude oil and natural gas in the Federal Republic of Germany: Development and prospects. J. Pet. geol. 4, 235-266.

Sorgenfrei, T. \& Buch, A. 1964: Deep tests in Denmark 19351959. Danm. geol. Unders., III rakke, 36, 1-146.

Stach, E., M.-Th. Mackowsky, M. Teichmüller, G. H. Taylor, D. Chandra \& R. Teichmüller 1975: Stach's Textbook of Coal Petrology. (2nd ed.). Gebrüder Borntraeger, Berlin, Stuttgart, $1-428$.

- 1982: Stach's Textbook of Coal Petrology (3rd ed.). Gebrüder Borntraeger, Berlin, Stuttgart, 1-535. 
Teichmüller, M. 1982: Origin of the petrographic constituents of coal. In: Stach, E. et al.: Stach's Textbook of Coal Petrology, 3rd ed. Gebrüder Borntraeger, Berlin, Stuttgart, 219-294.

Teichmüller, M. \& Ottenjann, K. 1977: Art und Diagenese von Liptiniten und lipoiden Stoffen in einem Erdölmuttergestein auf Grund fluoreszenzmikroskopischer Untersuchungen. Erdöl u. Kohle 30, 387-398.

Teichmüller, M. \& Teichmüller, R. 1958: Inkohlungsuntersuchungen und ihre Nutzanwendung. Geol. Mijnb. NW Serie $20(2), 41-66$.

Teichmüller, M. \& Teichmüller, R. 1966: Geological causes of coalification. In:Given, P. (ed.), Coal Science. Adv. Chem. Ser. 55, 133-155, Am. Chem. Soc., Washington.

Thomas, R. L., A. L. W. Kemp \& C. F. M. Lewis 1972: Distribution, composition and characteristics of the surficial sediments of Lake Ontario. J. Sed. Petrol. 42, 66-88.
Thomsen, E. 1980: Rank of coal and dispersed organic matter in Rhaetian-Jurassic- Lower Cretaceous deposits from the onshore part of the Danish Subbasin: Interpretation and implications for the maturity of potential hydrocarbon source rock. $\mathrm{Ph}$. D. thesis, Aarhus University 1980, unpublished, 1-268.

Thomsen, E., H. Lindgreen \& P. Wrang 1983: Investigation on the Source Rock Potential of Denmark. In: Kaaschieter, J. P. H. \& T. J. A. Rejers (eds.), Petroleum geology of the southeastern North Sea Area and the adjacent onshore areas. The Hague, 1982, Geol. Mijnb. 62, 221-239.

Tissot, B. P. \& Welte, D. H. 1978: Petroleum Formation and Occurrence. Springer Verlag, Berlin, Heidelberg, New York, 1-538.

Well Data Summary Sheets 1981: Volume 2. The Geological Survey of Denmark. 